\title{
Liberating Farmers from Tenancy Bondage: The Land and Agrarian Reform Programs of President Ramon Magsaysay (1954-1957)
}

\author{
Eric F. Portera \\ The Graduate School, University of Santo Tomas, Manila, Philippines \\ efportera@ust.edu.ph \\ https://orcid.org/0000-0003-4257-3360 \\ Antonio C. Hila \\ The Graduate School, University of Santo Tomas, Manila, Philippines \\ tonioan47@yahoo.com
}

\begin{abstract}
The past economic colonial policies in the Philippines created severe issues for land tenancy and distribution patterns. When Magsaysay won the presidency in 1953, his administration carried the banner of land and agrarian reform as its core policy. The paper investigated how Magsaysay Administration's agrarian reform policies addressed the needs of the peasants. Further, the study presents the land and agrarian reform programs enacted by the Magsaysay Administration, from conceptualization to implementation, their results, and efficacy in easing the tenancy problem of farmers. Using the historical method, the study showed that Magsaysay's land and agrarian reform program provided security of tenure to the farmers. It enabled them to become more independent, self-reliant, and responsible citizens. Ultimately, the program succeeded in protecting the farmers from the uncertainty and threat of land deprivation and, in effect, curtailed insurgency. Magsaysay's program also proved influential to succeeding administrations in the design and construction of their land and agrarian reform laws.
\end{abstract}

Keywords: History, Land and Agrarian Reform, Tenancy, Insurgency, Bondage, Ramon Magsaysay, Farmers, Philippines

Date Submitted: March 26, 2020

Date Revised: June 9, 2020

Date Accepted: June 15, 2020

\subsection{Introduction}

Some of the most pervasive threats to peace and order in the Philippines arise from land and tenancy relations, which happen to be the central issues in the nation's agricultural milieu (Estrella, 1974). As such, the conception and implementation of a viable land reform program have been the government's primary instrument towards the resolution of the land tenancy problems and, in effect, the preservation of peace and order. 
From the inception of the encomienda system during the Spanish era to the establishment and growth of the hacienda during the American colonial reign, the inequitable land distribution system that benefited landlords more than the tenants had long been a scourge on the backs of Filipino farmers. The consequent uprising by the disenfranchised and the government's usual attempts to pacify them through reform measures have become perennial and salient narratives in Philippine history (Kerkvliet, 1979).

By the end of the Spanish period, cultivated lands, located within Manila, were in possession of religious orders. As a result, the friar estates became the center of peasant hardship and unrest. The settlement of such discord became a matter of great importance and urgency to the Americans as their regime began, and agrarian problems persisted. Their colonial government was compelled to address the disturbance without further delay (Constantino, 1978). For instance, William Howard Taft introduced the "homesteading program". This program sought to convince Filipinos to reside in unpopulated areas to encourage the latter's cultivation and development (Shalom, 1986). However, the program failed to flourish due to the people's preference to remain in sitios and poblaciónes and refusal to abandon their farms (Agoncillo, 1990). Commonwealth President Manuel L. Quezon endeavored to support the colonial government's efforts by employing ameliorative measures as his predecessors did. President Quezon's "social justice program" mandated the regulation of tenancy relations, restoration of the land resettlement program and the establishment of the National Rice and Corn Corporation (NARIC), which aimed to monitor the purchase and selling prices of agricultural goods, and the agricultural credit fund under the "Rice and Corn Fund". At the onset of the Second World War the nation's attention and resources were inevitably rerouted to fighting the Japanese adversaries, thereby, diffusing the burgeoning confrontation between landlords and tenants (Wurfel, 1958). However, upon the war's conclusion, agrarian disturbance resurged. The Huk movement became a vessel by which the disorganized array of peasant challenges and complaints were expressed and represented coherently (Agoncillo, 1990).

In 1954, Magsaysay ran for president with land reform as his centerpiece program his brilliant track record as Defense Secretary, and the help of the American Government won him the presidency (Gleek, 1993).

As President, he lived up to his campaign promise. A sincere effort to alleviate the plight of landless peasants was begun. Through the legislation of land reform laws and its implementation, Magsaysay showed and made the peasants feel his sincere concern and determination to improve their situation in life, for these peasants loved him. A study of his land reform program is thus in order.

Therefore, this study evaluated the contributions of the Magsaysay Administration to land and agrarian reform in the Philippines (political, social, legal economic). It described and explained the land tenure situation and land and agrarian problems in Central Luzon as the primary reason for the unrest. Further, the study analyzed the land and agrarian reform laws and policies created by the Magsaysay administrations in terms of their effectiveness in easing the tenancy bondage of the tenants/farmers and, in turn, curbing the insurgency problem. 


\subsection{Methods}

The methodology adopted in this paper is the descriptive-analytical-narrative, otherwise known as the historical method, as advocated by M.C. Lemon (2003). He pointed out that writing history is source-based; hence, knowledge construction relies on available materials. To have a thorough understanding of the process of policymaking for land and agrarian reform programs, it is imperative to gather and obtain evidence and historiographic sources, both primary and secondary. These sources provided the direction, thrust, and structuring of the study (Scaff, 1982).

The study chronicled the dynamism of making land and agrarian reform programs focused on the governmentss actions to identify the problems, prioritize concerns, and bring out the needed reforms through statutes. This study first described the political, economic, and social conditions of the Philippines in each era of governance, starting with the Commonwealth government from 1935 to 1946 up to the administration of Ramon Magsaysay. After the discussion of the policy environment, the findings and recommendations of the land and agrarian reform program surveys and assessments were analyzed as they influence the drafting of land reform laws. Afterward, the interactions between policy actors in the executive and legislative branches leading to the passage of laws were put into the account that comprises the narrative component of this paper. This will lead to the last part, which is the discussion of the implementation of the laws by the executive branch through the Department of Agrarian Reform.

It is important to note that these inquiries followed the historical theme of continuity and change. The discussion did not focus on separate phenomena in stasis. However, it chronicled as a changing past in a continuum of the progress of land and agrarian reform programs.

This study relied fully on materials from government publications such as the Official Gazette of the Ramon Magsaysay Administration, government reports on the economy, and the Department of Agrarian Reform's accomplishments. The researcher culled other materials from journals, private publications, newspaper reports, and magazines.

The primary sources were original materials created contemporaneously with an event understudy, such as legal documents and government records. The study scrutinized the provisions on Land Reform Programs of the Constitutions of 1935 and 1973. The major enacted laws on Land and Agrarian Reform programs such as RA No.1199 of 1954, RA No.1400 of 1955, and RA No.3844 shall be analyzed together with other statutes supporting these land reform programs laws. Another primary source of information is the Official Gazette that contains the speeches, addresses, proclamations, and messages of President Magsaysay throughout their term of governance. It provided the executive branch's mindset regarding their perception of land reform programs that guided them in crafting policies.

The yearly Appropriations Laws passed by the Legislature were accessed and studied to discern how land reform programs became a priority throughout the different administrations. Other official documents, such as statistical reports on demographics and the economy from the period of 1950- 
1960, were also used. These data were culled from the Bureau of Census reports, which later became the National Census and Statistics Office (NCSO) under the National Economic Development Authority (NEDA). The news articles and editorials of major newspapers on the periods covered were probed to obtain the people's perception of the call for land reform and the speed of the legislative and executive branches' response. In particular, articles from the Manila Daily Bulletin, the Manila Times, and the Daily Express were included. Articles from magazines, such as the Philippine Free Press, and the Philippine Weekly Graphic, were likewise perused. Secondary sources are cited for enriching further the understanding of the land and agrarian reform programs of President Ramon Magsaysay. These included books, encyclopedia, scholarly articles, theses, and dissertations. These references provided differing analyses and interpretations of Land and Agrarian Reform programs.

\subsection{Result and Discussion}

\section{Land and Agrarian Reforms of Ramon Magsaysay}

Share tenancy was a symbiotic relationship wherein the landlord maximized his income from his property. At the same time, the tenants were assured of financial security. It may be said that such a relationship was feudalistic.

During the $20^{\text {th }}$ century, there was a drastic rise in share tenancy in Central Luzon. According to James Putzel:

\footnotetext{
"Tenancy in the Philippines increased from 16 percent in 1903 to 35 percent of the farming population just before World War II. Central Luzon, the center of rice production, saw even higher tenancy rates, particularly in Pampanga, Nueva Ecija, and Bulacan. Nueva Ecija tenancy went from 38 percent in 1903 to 54 percent just before World war II, and 60 percent by 1948."
}

As this was happening, the Philippine society was undergoing tremendous change. The economic orientation of the time was transforming into one that was capitalistic and to which the elite quickly adapted. However, the lower class of Central Luzon received a higher level of education than previous generations (Santiago, 2018). With their exposure to democratic and socialist ideals, this new awareness made them more aggressive in demanding rights that they believed they deserved (Dillon, 1968). Thus, the feudalistic nature of the relationship began to change. The landowners saw their land as a secure and profitable investment and the tenants, not anymore as sort of 'extended family' that looked up to the landlords like patriarchs as was in the past (Riedlinger, 1995). On the other hand, the tenants, agitated by their enlightened leaders, became more conscious of what they perceived as abuse and became more militant. In this light, the relationship became sour between the landlords and the tenants (Abueva, 1959).

As early as the 1920's, deep 'class feelings' against the landlords at work in Bulacan and Nueva Ecija had been noted. Later followed the growth of socialist and 
communist groups like the HUKBALAHAP, a group that the peasants of Central Luzon regarded as the defender of their interests. Landlords attempted to undermine the growing strength of the HUKBALAHAP by supporting the government's iron fist policy (Agoncillo, 1990).

In its effort to prevent the spread of communism, the Philippine Constabulary, which appeared to have been becoming the trend in Asia, waged campaigns to crush the HUKBALAHAP movement. The peasantry interpreted the anti-communist crusade as part of a grand scheme of the landlords and the government to perpetuate landed class dominance (Santiago 2018). An aggravating factor was the rampant abuse towards the peasantry committed by members of the Philippine Constabulary. This gave the peasants the impression that their government was against them (Gleek, 1993).

When Ramon Magsaysay was appointed Secretary of National Defense, he was able to gain the trust of the peasantry. His image as a man forms the masses. Also, a man who was feared and respected by the military gave hope to the common man that someone in the government was looking after him (Richardson, 2011). As discussed, disciplinary measures instituted in the military as well as other reforms in the armed forces by Magsaysay, together with increased pressure on the rebels, eventually led to the downfall of the HUKBALAHAP movement (Saulo, 1994).

His popularity with the people, especially the masses, after his hugely successful stint as Defense Secretary was so great that his destiny pointed to no other direction but towards the highest post in the land. In 1953, he ran for the presidency of the country. With the improvement of the lot of the common man as his campaign platform, he said: "I will devote 90 percent of my time to the improvement of our barrios if elected". He visited the most remote barrios and listened to anyone who had anything to say. He shook every hand along his way and showed the people that he was the man they needed as President. For this, the masses idolized him (Santiago, 2018). They saw in him not only a man who understood them but also a man who was going to change their lives. This charism helped Ramon Magsaysay become the president who would hold the record of winning with the largest vote in history (Dillon, 1968).

In 1954, President Ramon Magsaysay launched a two-pronged approach to land reform. It was initiated "to broaden the base of farm ownership by the breakup and subdivision of landed estates and resettlement in new areas" along with these programs," tenancy reform was initiated to transmute tenancy relations" into one which was just and equitable and at the same time " to prepare the tenant-farmer for the responsibilities of farm ownership (Constantino, 1975).

Land reform was carried out primarily through the enactment of two basic laws: The Agricultural Tenancy Act of 1954 (R.A. 1199), which governed tenancy relations, and the Land Reform act of 1955 (R.A. 1400) which became the fundamental law for the redistribution of land to the tiller.

Two additional laws were enacted, creating the Agricultural Tenancy Commission, also known as the ATC (A.O. 67) and the Court of Agrarian Relations of the CAR (R.A. 1267). The Agricultural Tenancy Commission was created as the agency for the implementation of R.A. 1199 and to assist the tenants who may be brought before the Court of Agrarian Relations which in turn, was created to adjudicate landowners and tenants. 
For support services, the Agricultural Credit and Co-operative Financing Administration (ACCFA) were created through R.A. 821. This agency was tasked to provide an adequate production credit system for small farmers. Also enacted was R.A. 1160, which created the National Resettlement and Rehabilitation Administration (NARRA). This agency was tasked to resettle tenant's areas to sparsely settled regions. The preciously established Bureau of Lands was in charge of public distribution and the approval of subdivision surveys.

The land reformers considered that many share tenants were unprepared for land ownership responsibilities, for everything he did on the farm was subject to the landlord's control and direction (Douglas, 1970). The situation prevented the tenant farmer from developing enough skills in managing his farm. Given this consideration, the Land Reform Committee envisioned a step by step process to ensure a smooth transition in the countryside. What was important was to establish a just and equitable tenancy relationship. What was first important was to create a just and fair tenancy relationship. The rights of the landlords and tenants had to be defined. Then the tenants would "be trained to become owners by graduating them from the status of the lowly "kasama" or share tenant to the more elevated status of a leaseholder. As a leaseholder, the tenant would assume responsibility of the farm management and, in the process, learn what was needed to run the farm efficiently and independently. This was made possible through the passage of the Agricultural Tenancy Act of 1954 (Santiago 2018).

\section{The Agricultural Tenancy Act of 1954}

On August 30, 1954, President Ramon Magsaysay approved R.A. 1199, otherwise known as "The Agricultural Tenancy Act" It sought to break the inertia of inaction in tenancy and pave the way to the ultimate ownership by the tenant of a piece of land he can cultivate. The act also assured him of an equitable tenant-landlord relationship that will promote the development of agriculture (Dillon, 1968).

This law gave the peasant the option to choose the type of tenancy system he would be in. It guaranteed the security of tenure of a tenant (Abensour, 1957) conferred on him more managerial rights, set the maximum limitation on land rentals, and made it possible for the tenant to receive more share in the harvest by giving him the right to contribute more to the items of production. It also codified and clarified the vague and scattered tenancy laws, detailed the rights and obligations of landlord and tenant, and reduced the interest rates and the creditor's liens on the tenant (Santiago 2018).

Essentially, the law divested the tenants of their liberties through the pretext of allowing them to choose the tenancy system to which they will be subordinate. These systems of agricultural tenancy were classified as leasehold and share tenancy. Share "tenancy "as defined in the law to exist, "whenever two persons agree on a joint undertaking for agricultural production wherein one party furnishes the land and the other his labor, with either or both contributing any one or several of the items of production, the tenant cultivating the land personally with the aid of labor available from members of his immediate farm household, and the produce thereof to be divided between the landholder and the tenant in proportion to their respective contributions."

Share tenancy was the traditional relationship between landlords and tenants, particularly in Central Luzon. It was also the system associated with the exploitation of 
the peasantry by the landowners. The tenants had no bargaining leverage because of their insecure tenure. A tenant could be ejected anytime if he did not accept the terms of the landowner, which thus made him prone to abuse (Douglas, 1970).

On the other hand, leasehold was said to exist, when " a person who, either personally or with the aid of labor available from members of his immediate farm household, undertakes to cultivate a piece of agricultural land susceptible of cultivation by a single person together with members of his immediate farm household, belonging to or legally possessed by, another in consideration of a price certain or ascertainable to be paid by the person cultivating the land either in the percentage of the production or in a fixed amount in money, or both."

This was the tenancy system under which the tenant did not just receive a share in his labor (Quirino, 1958). Instead, he paid the landlord a fixed amount as lease rental for the property (Agoncillo, 1990). Therefore, any improvement in his production was wholly for his benefit. While in shared tenancy, the landlord had a share in any increase in production. In leasehold, any improvements in production belonged to the tenant. Therefore, this also provided an incentive for the tenant to improve production (Rivera, 1952).

However, despite the evils associated with share tenancy, the members of Congress did not pursue its' abolition. Although it is a popular idea, that it was Congress itself that did not favor a radical transformation in the countryside, according to Senator Sumulong, Congress was guided by "the principle of the right civil determination of the peasants." The right self-determination was an underlying principle that Congress wanted to respect. That is why R. A. 1199 gave the peasant the option to choose between share-tenancy and leasehold tenancy; it also gave the peasant the option to choose the crop-share arrangement as recommended by Magsaysay, should he decide to maintain the share-tenancy relationship. Thus, the share tenant was given the full liberty to decide on the kind of life he would live if the tenant enjoyed the freedom of choice (Takahashi, 1969).

With the setting of the above guidelines, the landlords were prevented from coercing the tenants to do what they did not want to. The most significant aspect of the law was the security of tenure. It gives tenant farmers (Abueva, 1959). Based on the law, it emancipated the tenant from insidious fear of suddenly finding himself deprived of land to cultivate (Lava, 2002). The tenant is now protected in the peaceful pursuit of a productive endeavor. His continued tenure is assured even when the land is transferred from one landlord to another. Not even the expiration of a period provided for in a tenancy contract can restrict, much less destroy his security of tenure (Dillon, 1968).

Nevertheless, despite its' nature and purpose, the law went through turbulent waters before it could be passed and implemented. Several representatives in Congress belonged to the landed political elite, making the passage of the bill against their interests. By the time Congress passed the law, what was legislated was a watereddown version of its original. The law was also not accompanied by a companion law that would have created a "Court of Agrarian Relations." To make things worse, Congress failed to appropriate money for its implementation (Takahashi, 1969).

However, despite these setbacks, Magsaysay did not falter. "To salvage the situation," Magsaysay implemented the "Agricultural Tenancy Act" by forming the 
"Agricultural Tenancy Commission" on September 30, 1954, through Administrative Order No. 67 (Corpuz, 1997).

\section{Agricultural Tenancy Commission}

As an implementing agency of R.A. 1199, the Agricultural Tenancy Commission was tasked with a three-point objective. The first was to educate landholders and tenants of their rights and obligations. The second was to determine the suitability and adaptability of R.A 1199 to crops in different areas through survey and research. The third was to assist to the tenants and landholders in the amicable settlement of their tenancy disputes while maintaining harmony in their relationship (Mondoñedo, 1956).

In its first year, the ATC conducted 1,192 general meetings and conferences in 30 provinces. It distributed 904,388 educational materials. It had 278 press coverage and radio spots and participated in 6 exhibits, all these aside from the visits to the fields for the "preaching of the gospel of the barrios." These were information campaigns through which the public was informed of the rights granted by the Agricultural Tenancy Act (Santiago, 2018). With regard to the second objective, it investigated nine farms to determine its' suitability of mechanization, involving 766 tenants and 2, 2028.3 hectares. It also conducted farm surveys in 26 provinces. The third objective was met with mediation activities wherein 2,492 cases involving 15,060 tenants and landholders were included. It was also responsible for rendering of 12,652 legal opinions (Shalom, 1986). This office intervened in tenant-landlord disputes to redress inequalities in bargaining power and inequities in crop distribution.

\section{Court of Agrarian Relations}

After a year, the R.A. 1199's companion law was approved. On June 14, 1955, Republic Act No. 1267, which instituted the Court of Agrarian Relations, was passed (Agoncillo, 1990). The law prescribed its jurisdiction and established its rules and procedure. The law's primary function was to settle all tenancy disputeswhich were not resolved by the Agricultural Tenancy Commission. Further, the court was mandated by law to decide upon the cases within a fixed period(Froehlich, 1961). In its first year alone, the court received 2, 589 cases. This was more than all the cases filed with the tenancy division of the court of Industrial Relations in the previous three years. Nevertheless, the court was able to arbitrate and conclude all the cases and some 300 ones as well (Santiago, 2018).

In a speech delivered in the Senate in 1963, Raul S. Manglapus mentioned the existence of discontent and unrest in the relationship between the landlords and tenants. This is statistically proven by the hefty number of tenancy cases filed, pending, and disposed of in the Agrarian Court (Manglapus, 1967).

\section{The Land Reform Act of 1955}

On September 9, 1955, almost three months after the passage of R.A. 1267, President Magsaysay signed into law, R.A No. 1400, otherwise known as "The Land Reform Act of 1955". The act established a piece of machinery for the acquisition and redistribution of private agricultural land. Further, it defined a land tenure policy, provided an instrumentto carry out the system, and appropriated funds for its implementation(Motheral,1956). Indeed, itwas a land for the landless program. 
It was a more vigorous policy in the acquisition by the government of substantial land holdings, mostly on the vast plains of Central Luzon, where "absentee landlordism was common. Magsaysay introduced a bill in Congress, but although the Nacionalistas had a clear majority in both chambers of Congress, its' passage was hampered by a full year. It was only after the President called for a special session of Congress in 1955 that Republic Act No. 1400 was finally approved (Kerkvliet, 1979).

As a "supplement" to the Agricultural Tenancy Act, the Land Reform Act of 1955 was enacted for the acquisition of lands and for its' redistribution to farmers who were prepared for land ownership (Rivera, 1952). The idea was to break up significant landholdings into family-sized farms for distribution to tenants.

The main difference of this law from past legislation intended for land acquisition and redistribution was with the manner of acquisition of private agricultural lands. For a while before, the government took the initiative in the purchase of lands, now the acquisition of lands emanates from the tenants. Under the new Land Reform Act, the government will not take positive steps to acquire any privately owned agricultural lands unless the tenants themselves petition the administration (Putzel, 1992).

In case of an agreement of sale to be paid fully in negotiable land certificates, all the outstanding debts of the tenants to the landowner, evidenced in writing, shall be included in the price to be paid to the landowner. However, the increase in price as a result of such inclusion should not exceed 10 percent of the land's total cost (Quirino, 1958).

The constitutional right to property of the landowner was respected. The court determined the fair market value of the land, and payments were to be made entirely in cash unless the landowner himself was willing to be paid partly in stock or entirely in negotiable land certificates (Santiago 2018). The choice was solely in the landowner. The same privilege of adding the outstanding debts of tenants to the purchase was afforded the landowner should he agree to be paid partly in cash or entirely in negotiable land certificates (Mondoñedo, 1955). The choice was solely in the landowner. The same privilege of adding the tenants' outstanding debts to the purchase was afforded the landowner should he agree to be paid fully in negotiable land certificates.

With regard to the Land Tenure Administration, the implementing agency of the Land, which was the implementing agency of the Land Reform Act of 19555, Abueva stated that "within a year the LTA had investigated 60 of 251 petitions for expropriation. By June 1957, ten estates had been acquired by the LTA and other agencies and turned over to LTA management. The LTA executed with landless tenants 733 deeds of sale, involving 80 farms and 757 home lots (Abueva, 1971).

After the acquisition, the land was then subdivided and sold to the tenants. Payments for these subdivided lots were to be made in 25 equal annual installments (Santiago 2018). As an assurance that the credit needs of the tenants for consumption and production purpose are taken care of, the law required that the tenants first form a cooperative to be affiliated with a government financing collaborative agency (Abinales, 2005). This requirement had to be complied with before the government acquired any private agricultural land. As discussed before, the tenant relationship was also a credit system. It was a fact that purchasers of family-sized farms could not be successful owners unless they had adequate production credit. To this end, the ACCFA was tapped as an agency to provide support services in giving credit (Dela Costa, 1992). 


\section{Agricultural Credit and Cooperative Financing Administration}

Money lending was a significant source of revenue for some landlords. In some instances, income earned in lending almost equaled the rental share. Some believe that this kind of creditintendedto keep tenants in debt andpereniallyboundto the dominant class of landowners(Rivera 1952). To avoid exploitation and to provide an adequate production credit system for small farmers, the Agricultural Credit and Cooperative Administration (ACCFA) was formed (Mondoñedo, 1956).

The establishment of the ACCFA transpired as a result of the Mutual Security Agency'sprodding. It was established by the Administration of President Elpidio Quirino in 1952 but was not given sufficient funding(Santiago 2018). In 1955, Magsaysay revitalized the ACCFA,thereby,establishinga system of liberal credit specifically designed to meet the needs of the small farmer.In addition, the ACCFA also facilitated the organization of farmers' cooperatives as required by the "Land Reform Act of 1955."

\section{National Rehabilitation and Resettlement Administration}

In Magsaysay's first year as president, he asked Congress to replace the disorganized Land Settlement and Development Corporation (LASEDECO) with the National Resettlement and Rehabilitation Administration (NARRA). This agency was created primarily to resettle share tenants, mostly from the heavily tenanted areas of Central Luzon to sparsely settled regions, chiefly in Mindanao and Palawan (Quirino 1958). The agency was tasked to relocate share tenants who would be displaced by the division of estates into family-size farms. There were instances when the land area was insufficient to accommodate all the share tenants. Its function was not limited to resettlement. Aside from providing farm lots, work animals, and farm implements to facilitate cultivation, the NARRA also extended credit assistance in kind and advanced food rations. Further, it also helped organize community activities (Manglapus, 1967).

The NARRA, also in charge of resettling those who had been displaced, was able toresettle 10,651 families, 5,914 of which had come from areas with high tenancy. In the Fiscal year 1957, it served 21,587 settler families in 16 settlement projects. The administration also "provided the settlers with farm implements and subsistence aid. It subdivided land and issued patents. It even helped to organize community associations that under-took self-help projects" (Abueva, 1971).

Incidental to this was the expediting of the issuance of land titles. Magsaysay "encouraged the U.S. supported the modernization of patent- processing in the Bureau of Lands, which resulted in a tremendous speeding up in its work. Land Patents issued jumped from about 9,000 in 1953 to over 46, 000 in 1955" (Abueva, 1971).

\subsection{Synthesis}

Inasmuch as land and agrarian reform are rooted in political agenda, it remains to be a persistent demand of the public from elected officials. However, despite the various programs legislated and implemented by various administrations, land, and agrarian reform continues to be unresolved to this day (Carranza, 2015). The administrations of Manuel L. Quezon (1935-1941), Manuel Roxas (1946-48), Elpidio Quirino (1948-53), and Ramon Magsaysay (1954-56) conceived land reform programs which may have converged in some areas but, generally, had their distinct 
policy initiatives. However, a series of land reform legislation during the Magsaysay administration is seen by some as "the first significant legislation toward land reform in the post-war Philippines" (Wurfel, 1988).

The first step of the Magsaysay administration in pursuing land and agrarian reform was the passage of the Republic Act 1199 or the Agricultural Tenancy Act of 1954. This law codified and clarified the vague and scattered tenancy laws and detailed the rights and obligations of the landlord and tenant. This assured the farmers an equitable tenant-landlord relationship. It also protected the peasants or farmers from exploitation through guaranteed security of tenure, thus, emancipating them from the fear of suddenly finding themselves divested of land to cultivate. This act paved the way for the formation of the Agricultural Tenancy Commission, which served as its implementing agency (Richardson, 2011). The Agricultural Tenancy Commission conducted surveys to determine the extent of R.A. 1199's adaptability to different crops in different areas. It provided educational programs for educating landholders and tenants of their rights and obligations and offered them necessary assistance in settling tenancy disputes and maintaining harmony in their relationship. Another institution formed was the Court of Agrarian relations, which settled all tenancy disputes within a fixed period (Rivera, 1952).

The early success of the reform through the Agricultural Tenancy Act led to the passage of the Land Reform Act of 1955. This act focused on the acquisition and redistribution of lands to farmers for land ownership (Borras, 2008). This act conducted studies on land tenure problems throughout the country. It provided that expropriation would apply to private lands owned by corporations and initiated investigation in areas reporting land tenure difficulties and recommended appropriate action without delay. This act, in turn, served as the basis for the formation of the Agricultural Credit and Cooperative Financing Administration, which promoted the organization of cooperatives and established a system of credit designed to meet the needs of the small farmers. In addition, the agency helped the farmers in the export, import, and purchase of farm products. Through the Land Reform Act of 1955, the right to property between the landowners and farmers were respected and made the latter more independent, selfreliant, and responsible citizens (Froehlich, 1961).

Another contribution of the Magsaysay was the establishment of the National Rehabilitation and Resettlement Administration. It supplied farm lots, work animals, and farm implements to facilitate cultivation and provided resettlement for displaced farmers. The said agency also provided land patents and titles for the tenants under the leadership of Pres. Ramon Magsaysay and modernized the patent-processing and farm equipment with the aid of the United States government (Estrella, 1974).

The land and agrarian reform initiatives of the Magsaysay's administration featured tenets on land tenancy regulation, resettlement to public lands, and appropriation and redistribution of private grounds (Borras, 2008). President Magsaysay was mostly concerned and focused on the betterment of tenant-landlord relations. Because he found that injustice was spurred on by the landlord's oppression of tenants, President Magsaysay's recognition and determination to address this injustice was indeed a pillar of his administration; a lasting legacy by which he will be remembered fondly (Richardson, 2011). 
President Diosdado Macapagal acknowledged Magsaysay for making the boldest attempt at agrarian reform before his administration. However, he also noted that Magsaysay's efforts "suffered from the weakness of its predecessors: it attacked the tenancy system on the surface, not at the roots" (Macapagal, 1963). While Magsaysay pursued agrarian reform with fairness in mind, the situation involved a sharp difference in wealth, power, and prestige between the landlords and farmers. Therefore, any law intended to make the distribution of wealth more equitable had to be at the expense of those favored by the existing inequitable conditions. Nevertheless, the Land Reform Act of 1955 stipulated that the government will pay the landowners either full in cash or fully or partially inland certificates (Santiago, 2018).

\subsection{Conclusion}

President Ramon Magsaysay was able to give the right solution on the issue of land and tenancy that had been causing social unrest in the Philippines. The land and agrarian reform programs of the Magsaysay administration emphasized the rights of the oppressed. It ensured the well-being of the peasants, particularly in Central Luzon. It addressed their needs by giving them the security of tenure, protection from the landlords' abuses, and a fair share in the product of their labor. Empowering the peasantry became the opportunity for them to be free from the manacles of exploitation while achieving peace and order. It was able to control the raging insurgency during that time, deeply rooted in the struggle of the oppressed, especially the laborers. Though Magsaysay's term was cut short due to his untimely demise and despite the inherent flaws of his program, his quest in alleviating the plight of the landless peasant and pursuit for peace in the country was undeniably successful.

\section{REFERENCES}

Abensour, E. (1957). Principles of Tenancy Legislation: A Comparative Study. Rome: Food and Agriculture Organization of the United Nations, 155-161

Abinales, P. (2005). State and Society in the Philippines (2005). Pasig City: Anvil Publishing, Inc., 134-136

Abueva, J. Focus on the Barrio (1959). Quezon City: Phoenix Press, Inc., 1971. 213-214

Agoncillo, T. (1990). History of the Filipino People. Quezon City: Garotech Publishing, 45

Borras, S. (2008). Competing Views and Strategies on Agrarian Reform Volume II: Philippine Perspective.

Quezon City: Ateneo de Manila University Press. 46-49

Carranza, D. (2015). Agrarian reform and the difficult road to peace in the Philippine Countryside, 1-12

Constantino, R. (1978). The Philippines: A Continuing Past. Quezon City: The Foundation for Nationalist Studies, 56-60

Corpuz, O.D. (1997). An Economic History of the Philippines, Quezon City: University Press, 45-47

de la Costa H, S.J. (1992). Readings in Philippine History. Manila: Bookmark, Inc., 78-79

Dillon, D. (1968). Land Reform. Manila: Thomas Jefferson Cultural Center in Manila, 67-69

Douglas, D. (1970). A Historical Survey of the Land Tenure Situation in the Philippines, 56-60

Estrella, C. (1974). The meaning of Land Reform, Manila: Solidaridad Publishing House, 79-82

Froehlich, W. (1961). Land Tenure, Industrialization, and Social Stability: Experiences and Prospects in Asia.

Wisconsin: Marquette University Press, 56-59.

Gleek, L. (1993). The Third Philippine Republic, 1946-1972. Quezon City: New Day Publishers, 78-79

Kerkvliet, B. (1979). The Huk Rebellion: A Study of Peasant Revolt in the Philippines. Quezon City: New Day Publishers, 67-70.

Lava, J. (2005). Memoirs of a Communist. Pasig City: Anvil Publishing, Inc., 2002.Martinez, Manuel F. (Ed. By Nelson A. Navarro), Magsaysay, the People's President. Makati City: RMJ Development Corporation, 89-90. 
Lemon, M.C. (2003). Philosophy of History. London: Taylor \&Francis Ltd, 34-35

Macapagal, D. (1963). An Act of Emancipation, President Macapagal's address at the singning of the Agricultural Land Reform Code. Manila: Official Gazette 59 No. 32.

Manglapus, R. (1967). Land of Bondage, Land of the Free: Social Revolution in the Philippines 37-50

Mondoñedo, O. (1956). "Agricultural Credit and Cooperative Financing Administration (ACCFA)," Agricultural Credit in the Far East, Proceedings of the First Agricultural Credit Workshop. ManilaBaguio 82-86

Motheral, J. (1956). "Land Tenure in the Philippines," Journal of Farm Economics 38 No. 2. 465-474.

Putzel, J. (1992). A Captive Land: The Politics of Agrarian Reform in the Philippines. Quezon City: Ateneo de Manila University Press, 34-36.

Quirino, C. (1958) Magsaysay of the Philippines. Makati: Carmelo \& Bauerman, Inc., 34-40.

Riedlinger, J. (1995). Agrarian Reform in the Philippines: Democratic Transitions and Redistributive Reform, 57-60

Richardson, J. (2011). Komunista: The Genesis of the Philippine Communist Party, 1902-1935. Quezon City: Ateneo de Manila University Press, 78-79.

Rivera, G. (1952). The Rural Philippines. A Cooperative Project of the Philippine Council for United States Aid and the United States Mutual Security Agency. Manila: Mutual Security Agency, 127-140

Saulo, A. (1994). Communism in the Philippines, An Introduction-Enlarged Edition. Quezon City: Ateneo de Manila University Press, 35-45.

Santiago, F. (2018). Towards the Happiness of the "common man" The agrarian reform in a time of the president Ramon Magsaysay, 1-22

Scaff, A. (1982). Current Social Theory for Philippine Research Quezon City: New Day Publishers, 23-25.

Shalom, S. (1986). The United States and the Philippines, A Study of Neocolonialism. Quezon City: New Day Publishers, 56-59.

Takahashi, A. (1969). Land and Peasants in Central Luzon, Honolulu: East-West Center Press, 88-90

Wurfel, D. (1958). "Philippine Agrarian Reform under Magsaysay," Far Eastern Survey, 27 No. 1, 7-15. 